\title{
Linking Nanoscale Dynamics of AMPA Receptor Organization to Plasticity of Excitatory Synapses and Learning
}

\author{
DDaniel Choquet ${ }^{1,2,3}$ \\ ${ }^{1}$ Centre National de la Recherche Scientifique, Interdisciplinary Institute for Neuroscience, Unité Mixte de Recherche 5297, F-33000 Bordeaux, France, \\ 2University of Bordeaux, Interdisciplinary Institute for Neuroscience, Unité Mixte de Recherche 5297, F-33000 Bordeaux, France, and ${ }^{3}$ Bordeaux Imaging \\ Center, UMS 3420 Centre National de la Recherche Scientifique, Université de Bordeaux, US4 INSERM, F-33000 Bordeaux, France
}

The spatiotemporal organization of neurotransmitter receptors in the postsynaptic membrane is a fundamental determinant of synaptic transmission and thus of information processing by the brain. The ionotropic AMPA subtype of glutamate receptors (AMPARs) mediate fast excitatory synaptic transmission in the CNS. The number of AMPARs located en face presynaptic glutamate release sites sets the efficacy of synaptic transmission. Understanding how this number is set and regulated has been the topic of intense research in the last two decades. We showed that AMPARs are not stable in the synapse as initially thought. They continuously enter and exit the postsynaptic density by lateral diffusion, and they exchange between the neuronal surface and intracellular compartments by endocytosis and exocytosis at extrasynaptic sites. Regulation of these various trafficking pathways has emerged as a key mechanism for activity-dependent plasticity of synaptic transmission, a process important for learning and memory. I here present my view of these findings. In particular, the advent of super-resolution microscopy and single-molecule tracking has helped to uncover the intricacy of AMPARs' dynamic organization at the nanoscale. In addition, AMPAR surface diffusion is highly regulated by a variety of factors, including neuronal activity, stress hormones, and neurodegeneration, suggesting that AMPAR diffusion-trapping may play a central role in synapse function. Using innovative tools to understand further the link between receptor dynamics and synapse plasticity is now unveiling new molecular mechanisms of learning. Modifying AMPAR dynamics may emerge as a new target to correct synapse dysfunction in the diseased brain.

Key words: Synaptic plasticity; AMPA receptors; receptor trafficking; super resolution imaging; Long Term Potentiation; neurodegenerative diseases

\section{Introduction}

How and where memories are stored in the brain network is one of the fundamental questions in brain and cognitive sciences. In his seminal treaty, "The organization of behavior" (Hebb, 1949), Hebb made a first attempt to link these two lines of inquiry by proposing that the basic mechanism by which memories are stored in the brain is the activity-dependent enhancement of synaptic strength between contacting neurons. Since the initial identification and naming of synapses (Foster and Sherrington, 1897), our view and understanding of their organization and role in brain function have evolved considerably, and continue to do

Received Aug. 17, 2018; revised Sept. 21, 2018; accepted Sept. 21, 2018.

This work was supported by Ministère de l'Enseignement Supérieur et de la Recherche, Centre National de la Recherche Scientifique, ERC Grant ADOS, and the Conseil Régional de Nouvelle Aquitaine. I thank Angela Getz, Françoise Coussen, David Perrais, and Eric Hosy for critical suggestions on this manuscript; and the many outstanding members of my team and collaborators that participated to the results presented here over the years.

The authors declare no competing financial interests.

Correspondence should be addressed to Dr. Daniel Choquet, Centre National de la Recherche Scientifique, Interdisciplinary Institute for Neuroscience, Unité Mixte de Recherche 5297, F-33000 Bordeaux, France. E-mail: daniel.choquet@u-bordeaux.fr.

DOI:10.1523/JNEUROSCI.2119-18.2018

Copyright $\odot 2018$ the authors $\quad 0270-6474 / 18 / 389318-12 \$ 15.00 / 0$ so. A large body of evidence suggests that persistent modifications in the strength of preexisting synaptic connections, generally termed synaptic plasticity, are a primary mechanism for the formation of memory engrams that lead to learning (Martin et al., 2000; Malenka and Bear, 2004; Kessels and Malinow, 2009; Poo et al., 2016). Decades of work on the molecular mechanisms of synaptic plasticity have led to a better understanding of the signaling pathways and changes in dynamic organization of synaptic components that lead to rapid and enduring activitydependent changes in synaptic strength (Choquet and Triller, 2013; Huganir and Nicoll, 2013; Henley and Wilkinson, 2016). However, we still do not know precisely how stable changes in synaptic strength are induced or where and when synaptic plasticity comes into play to encode learning paradigms in a given neuronal network.

A key turning point in our understanding of how the brain stores memories is universally recognized as the discovery of activity-induced LTP (Bliss and Lomo, 1973), and then LTD (for review, see Pinar et al., 2017), of central synapses in the 1970s. This sparked the interest of a whole generation of neurobiologists in studying synaptic plasticity and its relation to memory (Martin et al., 2000; Malenka and Bear, 2004; Kessels and Malinow, 2009; 
Collingridge et al., 2010; Poo et al., 2016). Interestingly, these initial observations were not immediately put into perspective with another important contemporary finding according to which the biochemical nature of membranes was a fluid, rather than static, mosaic of lipids (Singer and Nicolson, 1972). Indeed, in the search for the cellular and molecular basis of synaptic plasticity, researchers initially concentrated on modifications of either transmitter release or gating properties of receptors already present at synaptic sites before plasticity induction. It is only at the turn of the 21st Century (Malinow and Malenka, 2002; Choquet and Triller, 2003; Newpher and Ehlers, 2008) that neuroscientists realized that the regulated dynamic exchange of synaptic components, allowed by the fluid nature of membranes, is also an important mechanism for activity-dependent synaptic plasticity.

\section{At first, a static view of synapses}

The static view of central synapses, where movements of postsynaptic elements would only occur during synaptogenesis to bring receptors in place, prevailed for many years. It was fueled by several factors. The neuromuscular junction was used initially as a model for understanding the molecular organization of the CNS synapses, and a dogma from the neuromuscular junction was that synaptic nAChRs are very stable with minimal dynamic regulation (Sanes and Lichtman, 1999). This concept was reinforced at central synapses by ultrastructural studies that revealed a precise subsynaptic organization of glycine receptors and their associated proteins in the postsynaptic membrane (Triller et al., 1985). In addition, electron microscopy initially only detected low levels of extrasynaptic AMPARs (Baude et al., 1995). The local enrichment of receptors at postsynaptic densities (PSDs) was proposed early to result from receptor interaction with stable elements (Triller et al., 1985; Betz et al., 1991). The main scaffold protein for glutamate receptors (i.e., PSD95) was formally identified in the mid-1990s (Cho et al., 1992; Kornau et al., 1995), and this further reinforced the concept of the stability of synaptic components.

A role for diffusion of receptors in the plasma membrane was actually postulated quite early as a mechanism for the formation of synapses and acetylcholine receptor accumulation at the neuromuscular junction (Axelrod et al., 1976; Poo, 1982), and later for AMPARs during synaptogenesis of central synapses (Craig et al., 1994; Mammen et al., 1997a). However, this notion did not really percolate to the rest of the neuroscience field, and the initial observations were largely overlooked. The resulting simplistic view that receptors were immobile at central synapses prevailed until we directly established their mobility (Meier et al., 2001; Borgdorff and Choquet, 2002) and the intrinsic reversibility of receptor-scaffold protein interaction was taken into account (Choquet and Triller, 2003; Ehrensperger et al., 2007).

\section{The search for the cellular and molecular basis of synaptic plasticity}

In the meantime, intense research aimed to unravel the cascade of events underlying LTP and LTD. An important step forward came from the demonstration of the role of NMDA receptors (NMDARs) in the plasticity of AMPAR-mediated responses (Collingridge et al., 1983), indicating a postsynaptic site of LTP induction. A key aspect is that calcium influx through NMDARs leads to activation of CaMKII (Kennedy et al., 1983; Barria et al., 1997), which is thought to be essential in many of the downstream events in LTP induction and maintenance. Although NMDARs are clearly postsynaptic, whether the synaptic potentiation resulting from their activation stemmed from presynaptic or postsynaptic changes remained a matter of intense debate (Bredt and Nicoll, 2003; Bliss and Collingridge, 2013; Nicoll, 2017). A major argument for the changes in the efficacy of synaptic transmission being presynaptic was the observation of decreased failure rate in observing series of postsynaptic response to presynaptic stimulations. This was hypothesized to result from an increase in the probability of transmitter release (e.g., Malinow and Tsien, 1990; Kullmann and Nicoll, 1992; Larkman et al., 1992). The discovery of silent synapses (Isaac et al., 1995; Liao et al., 1995) provided a postsynaptic explanation for the decrease in synaptic failure rate during LTP. Silent synapses harbor NMDAR but only low levels or no AMPAR. They can be turned into AMPA-active synapses via the insertion of AMPARs into the postsynaptic membrane triggered for example by LTP induction.

Further direct evidence for the postsynaptic expression mechanism of LTP came from glutamate uncaging experiments (Matsuzaki et al., 2004; Harvey and Svoboda, 2007), in which repetitive activation of NMDARs on a single spine resulted in a long-lasting increase in the AMPAR responses to glutamate uncaging from the same spine. Although it is now widely accepted that the expression of LTP is largely postsynaptic, a presynaptic component may well contribute under some conditions and at specific synapses (see Emptage et al., 2003; Ward et al., 2006; Bliss and Collingridge, 2013). This is particularly the case for NMDAR-independent forms of LTP (Grover and Teyler, 1990; Zakharenko et al., 2001; Nicoll and Schmitz, 2005), for instance, LTP at the DG to CA3 mossy fiber synapse.

Although it was becoming increasingly evident that the expression of LTP and LTD occurred, in most cases, by postsynaptic variations in AMPAR responses, the underlying mechanisms were less clear. While pioneering and overlooked work had suggested that increases in glutamate receptor numbers at synapses could underlie synaptic potentiation (Lynch and Baudry, 1984), the initial focus of the field was on modification of the gating properties of AMPAR already present at the synapse prior plasticity induction. There was, for example, the indication that induction of hippocampal CA1 LTP is associated with an increase in single-channel conductance of AMPARs (Benke et al., 1998) as a result of CaMKII-induced phosphorylation of GluA1 (Derkach et al., 1999; Kristensen et al., 2011). More generally, phosphorylation of the GluAl AMPAR subunit at S845 and S831 was established to play especially important roles during synaptic plasticity (Roche et al., 1996; Mammen et al., 1997b; Huganir and Nicoll, 2013).

\section{AMPAR trafficking as a central element of synaptic plasticity} At the turn of the 21st Century, the concept of AMPAR trafficking and its role in regulating AMPAR number at synapses began to emerge. The first direct evidence for the rapid accumulation of AMPARs at the synapse during LTP used overexpression of homomeric GluA1 receptors (Shi et al., 1999; Hayashi et al., 2000). Activity-driven insertion of GluA1 homomers at synapses could be measured based on their electrophysiological properties and the direct visualization of GluA1 tagged with GFP at spines (Shi et al., 1999). Earlier evidence, blocking postsynaptic vesicle fusion to the plasma membrane, had indicated that dynamic trafficking between intracellular compartments and the cell surface was important for the expression of LTP (Lledo et al., 1998) and LTD (Lüscher et al., 1999; Lüthi et al., 1999). Moreover, a direct interaction between NSF and GluA2 was suggested to be important for basal maintenance of AMPARs at the neuronal surface (Nishimune et al., 1998; Noel et al., 1999). Together, these studies prompted the emergence of the following concepts: (1) AMPARs are in constant turnover between the cell surface and intracellular 
compartments; (2) LTD is associated with increased AMPAR internalization; and (3) LTP is associated with increased AMPAR exocytosis. While these were important propositions, the lack of evidence for a direct insertion or retrieval of AMPARs at the PSD left an open question about how AMPARs exchanged between synaptic and intracellular compartments. The fluid property of membranes indicated that lateral diffusion within the plane of the membrane might be an alternative trafficking route.

\section{AMPAR surface diffusion and synaptic plasticity}

Detection of AMPAR surface diffusion and dynamic exchange between synaptic and extrasynaptic sites

Starting my group in Bordeaux, my initial project had little to do with neuroscience and aimed to carry on my postdoctoral work on membrane dynamics in migrating cells. However, being embedded in a neuroscience environment, I was struck by the overall neglect of the possible role for diffusion of membrane proteins in existing models of the synapse. I thus decided to investigate whether neurotransmitter receptors might move in the neuronal surface as membrane proteins in any other cell do. I was joined in this endeavor by Antoine Triller, a fine neuroscientist and an old friend, who had become interested in the possibility that central inhibitory glycine receptors (GlyRs) might diffuse in the plane of the membrane (Rosenberg et al., 2001) as AChRs do at the developing neuromuscular junction (Poo, 1982). Together with his student Jochen Meier, in probably my most exciting collaboration as a young scientist, we established that GlyRs alternate constantly between a mobile state, in which they diffuse in the plane of the neuronal membrane by Brownian motion (i.e., random movements powered by thermal agitation of molecules) and an immobile state, in which they are reversibly stabilized by the scaffold protein Gephyrin (Meier et al., 2001). To demonstrate this property, we tracked the movement of rather bulky $0.5 \mu \mathrm{m}$ latex beads bound to the extracellular domain of the receptors. It is worth mentioning that, although the approach was relatively rudimentary, all the basic findings of this early work have been confirmed with more recent and sophisticated single-molecule tracking approaches. This finding launched a series of studies by our two groups to describe the surface diffusion of inhibitory and excitatory receptors and deciphering the role of this diffusion in tuning neuronal function (Choquet and Triller, 2013). Welcomed at first with skepticism, this pathway of receptor trafficking is now recognized as a central mechanism regulating receptor numbers at synapses, both in basal states and during activity-dependent plasticity (Newpher and Ehlers, 2008; Henley et al., 2011; Granger et al., 2013; Roth et al., 2017; Hastings and Man, 2018).

I first reported the surface diffusion of AMPARs and its reversible stabilization at synaptic sites in 2002 (Borgdorff and Choquet, 2002). In this first study, we had already found that increases in intracellular calcium, such as the ones that occur during LTP, induce a rapid and profound immobilization of AMPARs. We immediately proposed that this activity-dependent diffusion-trapping mechanism might contribute directly in the accumulation of AMPARs at synapses during LTP. It indeed had all the properties that would be expected for increasing receptor numbers during activity-dependent plasticity, such as NMDAR and calcium dependence, rapidity, and input specificity. As for GlyR (Meier et al., 2001), we found that AMPARs alternate through a dynamic equilibrium between periods of Brownian diffusion and periods of immobilization through binding to more stable elements linked to the cyto-architecture. This led to the general notion of reversible diffusion-trapping that is mediated by the intrinsic reversibility of receptor-scaffold interactions
(Choquet and Triller, 2003; Ehrensperger et al., 2007). Neurons make a wise use of this robust and energy-saving mechanism to allow plasticity to happen with precision and input specificity, without necessarily needing exceedingly precise or complex strategies. This concept stood in contrast to the view at the time, of synapses as highly organized and relatively static structures.

We and others then went on to study the properties and regulation of receptor surface diffusion. Progress in this area has crucially relied on new methodological developments. For example, in a very fruitful collaboration with the physics group of Laurent Cognet and Brahim Lounis in Bordeaux, we developed the use of singlemolecule tracking that allowed visualizing AMPAR movements inside synapses (Tardin et al., 2003) (Fig. 1). We also introduced the U-PAINT technique, which allows high-density mapping of single endogenous receptor dynamics (Giannone et al., 2010). This complemented the development of single QDot tracking by Antoine Triller and the dearly missed Maxime Dahan (Dahan et al., 2003). The high mobility of extrasynaptic AMPAR and the capacity of synaptic AMPAR to rapidly exchange with the extrasynaptic pool were independently confirmed by Fluorescence Recovery After Photobleaching experiments (e.g., Ashby et al., 2006; Sharma et al., 2006; Jaskolski et al., 2009; Makino and Malinow, 2009). Together, these studies indicated that $\sim 30 \%-50 \%$ of synaptic AMPARs are mobile and can exchange with the extrasynaptic pool. However, it is only 15 years after our initial description of activity-dependent AMPAR diffusion-trapping that we have been able to properly address the role of AMPAR diffusion during physiological LTP (Penn et al., 2017), largely due to the limitations that confined single-molecule tracking approaches to experiments in primary neuronal culture models.

Revealing the high mobility of extrasynaptic AMPAR and their exchange between synaptic and extrasynaptic membranes led us to propose a model in which the number of AMPARs at synapses, which sets synaptic efficacy, results from a dynamic equilibrium between intracellular, extrasynaptic, and synaptic compartments (Triller and Choquet, 2005) (Fig. 2). This proposal was supported by electron microcopy and patch-clamp studies, indicating that extrasynaptic membranes of hippocampal pyramidal neurons contain an unexpectedly large number of AMPARs that could serve as a reserve pool for dynamic exchange between synaptic and extrasynaptic sites by lateral diffusion (Matsuzaki et al., 2001; Andrásfalvy et al., 2003; Fukaya et al., 2006; Masugi-Tokita and Shigemoto, 2007; TaoCheng et al., 2011). As a side note, a recent study using new small QDots (Lee et al., 2017) failed to detect a sizeable population of mobile AMPAR, which seems at odds with the body of literature reported above.

In addition, it is now well established that AMPAR surface diffusion and exchange between synaptic and extrasynaptic sites are highly regulated processes underlying functional synaptic changes that occur during development, activity-dependent plasticity (Makino and Malinow, 2009; Opazo et al., 2010), aging (Martin et al., 2014), and various pathological conditions (e.g., stress, Alzheimer's disease models) (Groc et al., 2008; Choquet and Triller, 2013; Kneussel et al., 2014; Opazo et al., 2018) and Huntington's disease (Zhang et al., 2018). This likely reflects the fundamental importance of controlling their number at synapses in a highly adjustable way to set the efficacy of excitatory synaptic transmission. Together, the extrasynaptic membrane thus appears as a key cellular compartment involved in AMPAR trafficking in plasticity.

\section{AMPAR surface trafficking and internalization in LTD}

In parallel to our findings that AMPARs are reversibly trapped at synaptic sites and diffuse within synapses (Tardin et al., 2003), 

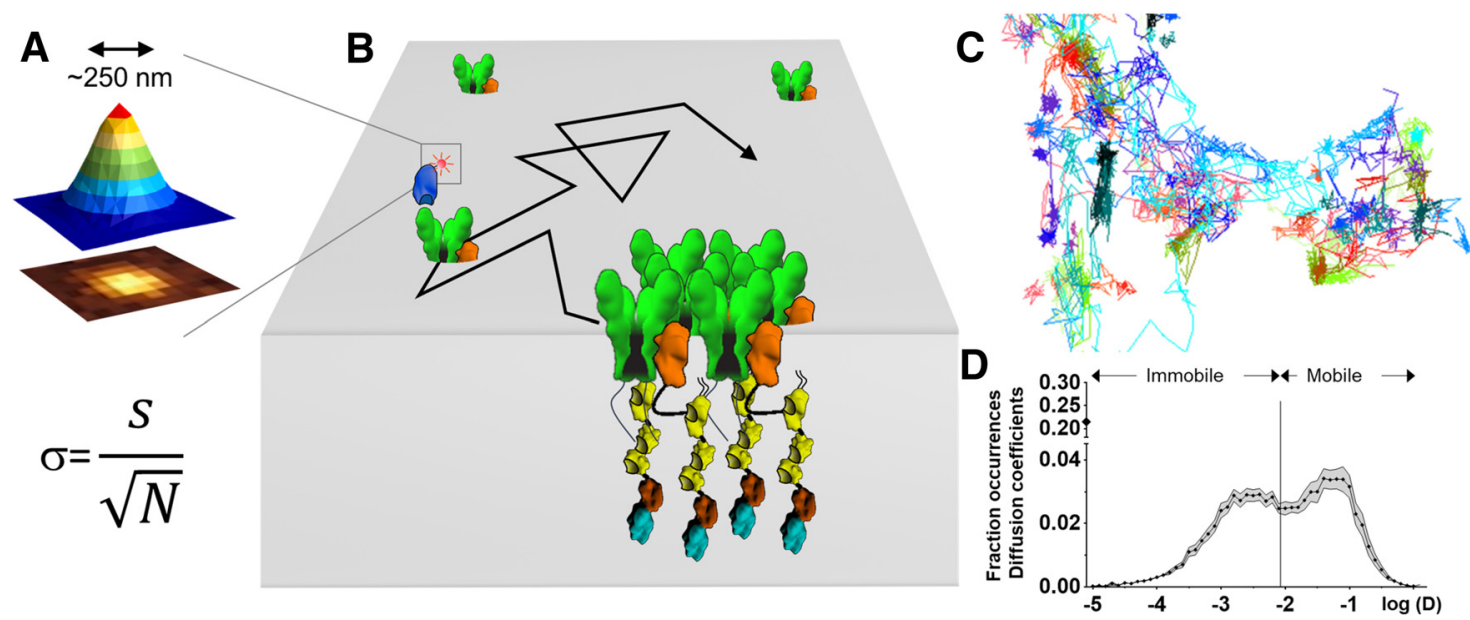

Figure 1. Single-molecule tracking of AMPARs in the plasma membrane. $A$, Because of diffraction, photons emitted by a single dye distribute according to a point-spread function that can be approximated by a Gaussian with FWHM approximately half the wavelength of the emitted light (i.e., $250-300 \mathrm{~nm}$ ). This Gaussian can be fitted to localize the individual molecules with an SE ( $\sigma$ ) (uncertainty) equal $S$ divided by $N^{0.5}$ where $S$ is the SD of the Gaussian and $N$ is the number of photons captured from the fluorescent molecule. $B$, individual AMPARs can be tracked with $20-50 \mathrm{~nm}$ accuracy by detecting over time single fluorophores bound to the receptors. Fluorophores can be either fluorescent proteins genetically fused to the receptors or organic dyes covalently bound to ligands of the receptors. These are usually full or the antigen-binding Fab fragments of antibodies. Combining small monovalent ligands and organic dyes provides the highest accuracy and allows tracking endogenous receptors. Using this approach, the stochastic nature of receptor movement in the plane of the membrane as well as their continuous alternation between stabilized and diffusive states are revealed. C, Tracks of GluA2-containing AMPAR movements at the surface of a dendritic spine of a cultured rat hippocampal neuron. $D$, Distribution of AMPAR diffusion coefficients in spines. Approximately 30 to $50 \%$ of the receptors are mobile with a $D>0.01 \mu \mathrm{m}^{2} / \mathrm{s}$.

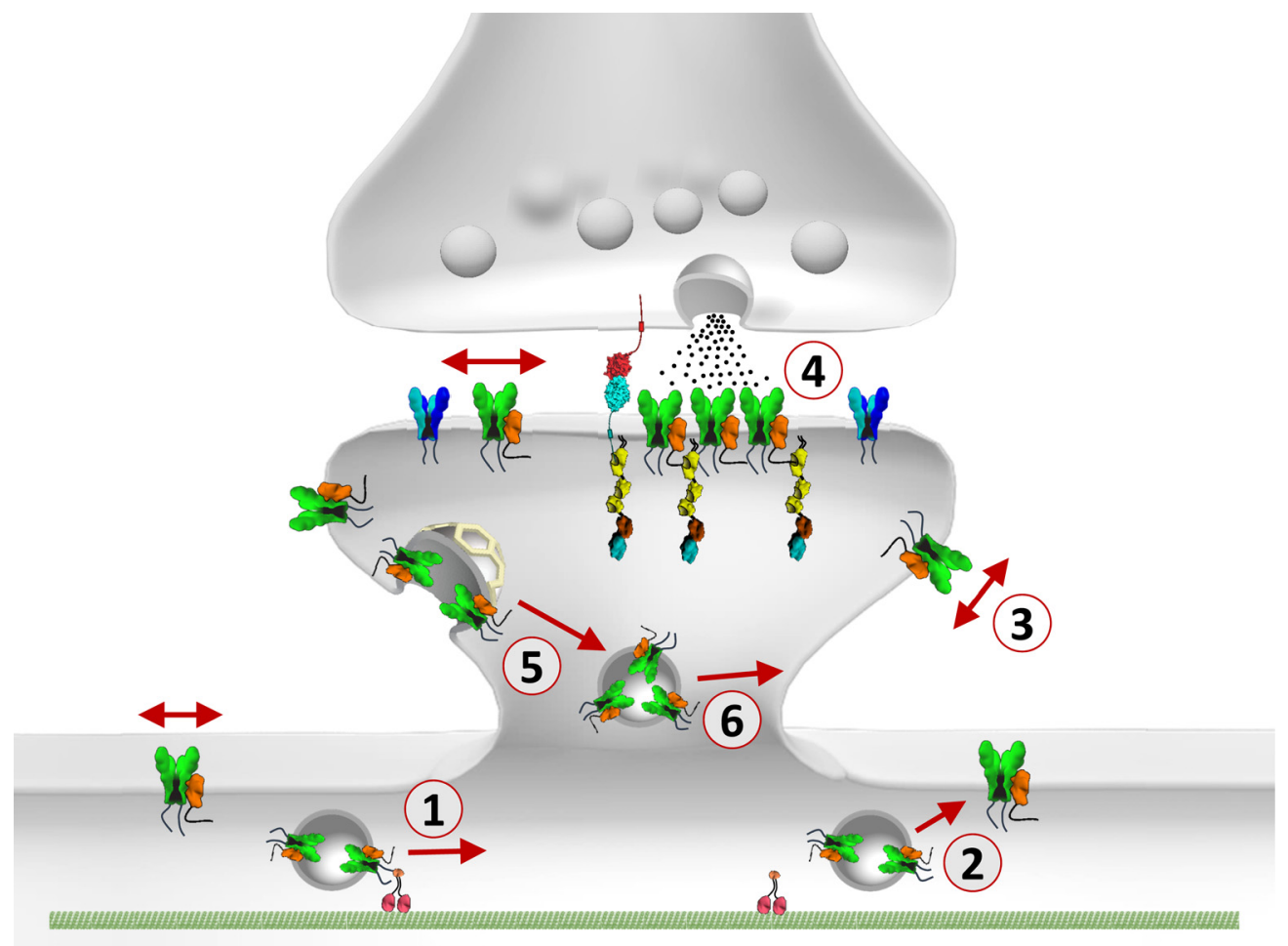

Figure 2. Model of AMPAR trafficking in and out the postsynaptic density. (1) Newly synthetized receptors are transported intracellularly in vesicles by molecular motors on microtubules. (2) Vesicles are exocytosed, largely in the dendritic shaft. (3) Once at the cell surface, receptors move randomly by Brownian diffusion and (4) can be reversibly stabilized by diffusion trapping at the PSD through interaction with scaffold proteins. (5) Diffusing receptors are internalized at extrasynaptic endocytic zones by clathrin-dependent endocytosis. (6) Endocytosed receptors can be recycled back by exocytosis.

several contemporary studies completed our vision of the pathways that underlie the dynamic equilibrium of receptors. In an elegant set of studies, it was established that sites of endocytosis lie lateral to the PSD (Blanpied et al., 2002; Rácz et al., 2004), whereas removal of AMPARs from synapses is preceded by transient endocytosis of extrasynaptic AMPARs (Ashby et al., 2004).
AMPAR internalization has been reproducibly observed during chemically induced LTD (Carroll et al., 1999, 2001; Lissin et al., 1999; Lin et al., 2000; Ashby et al., 2004) and inhibition of AMPAR internalization blocks activity-induced LTD (Lüthi et al., 1999; Beattie et al., 2000; Man et al., 2000). While there is to date no direct evidence for an increase in AMPAR diffusion dur- 

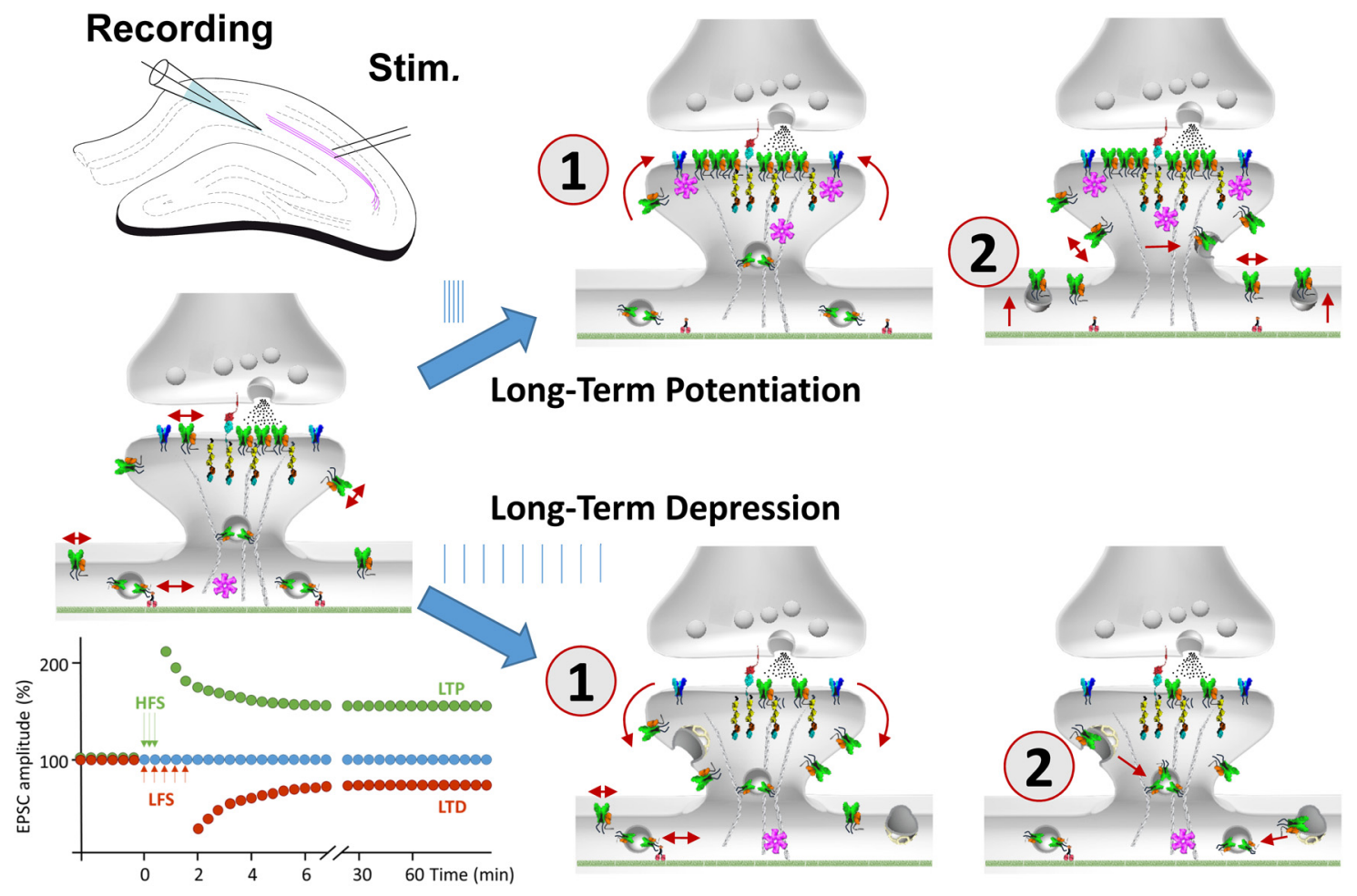

Figure 3. AMPAR trafficking during the first steps of LTP and LTD. The molecular mechanisms of synaptic plasticity have been best worked out at the synapses between Schaeffer collaterals and CA1 pyramidal cells in the hippocampus (top). Stimulation (Stim.) of Schaeffer collaterals induces rapid plasticity of synaptic transmission that can endure for hours to days (bottom left). High-frequency stimulation (top schemes) induces within seconds translocation of CaMKII (pink) to spines, and subsequent phosphorylation of the $\gamma 2$ and $\gamma 8$ AMPAR auxiliary subunits. This leads to their increased binding to PSD95 resulting in accumulation of AMPARs at the PSD through a process of diffusion-trapping (1). In parallel, intracellular receptors, whether newly synthetized or from recycling compartments, are exocytosed within minutes of the stimulation, largely in the dendritic shaft, but also in the spine (2). These exocytosed receptors then replenish the extrasynaptic pool and further diffuse to the synapse. Conversely, low-frequency stimulation (bottom schemes) induces AMPAR escape from the PSD (1). These escaped receptors then diffuse and get trapped at endocytic zones in the spine or in the dendritic shaft where they enter the endocytic pathway (2). These first steps lead to LTP and LTD, respectively.

ing LTD or for a strict dependence of LTD on AMPAR diffusion, the fact that sites of internalization lie away from the PSD renders obligatory a diffusional step between AMPAR unbinding and diffusion from the PSD before endocytosis (Fig. 3).

The identity of the protein interactions at the PSD that would be weakened to account for AMPAR escape and subsequent LTD is not clear. However, transient dephosphorylation of GluA2, GluA1, or the Transmembrane AMPA receptor Regulatory Proteins (TARP) auxiliary subunits at CA1 synapses (Lee et al., 2000; Tomita et al., 2005), or phosphorylation of GluA2 at Ser880 (Chung et al., 2003; Steinberg et al., 2006) at climbing fiber Purkinje cell synapses, leads to increased AMPAR endocytosis and reduced surface AMPAR expression, probably consequently to unbinding from GRIP or binding to clathrin adaptor proteins (Chung et al., 2000). The enzymes involved in LTD that might affect AMPAR stabilization include in particular protein kinase $\mathrm{C}$ (Chung et al., 2000) and the phosphatase calcineurin (Mulkey et al., 1994; Zeng et al., 2001).

Our recent work has established that, in basal conditions, perisynaptic endocytic zones preferentially internalize synaptic receptors (Rosendale et al., 2017). While the frequency of AMPAR endocytic events increases after the induction of NMDAR-dependent chemical LTD, the activity of perisynaptic endocytic zones is not differentially regulated and internalization can occur throughout the dendrite. This further reasserts the presumed role of AMPAR diffusion in leaving the PSD. However, the respective roles of AMPAR endocytosis, diffusion, and escape from synapses in mediating the activity-dependent decrease of AMPAR numbers at synapses during LTD remain to be established.
Interestingly, several pathology-related synaptic dysfunctions are associated with increased AMPAR surface diffusion and subsequent internalization. Alzheimer's disease has been termed a synaptopathy, and there is a strong correlation between progression of the disease and synapse loss (Selkoe, 2002). Although the underlying mechanism is mysterious, various models of the disease exhibit deficits in AMPAR-mediated synaptic transmission and plasticity that might be directly linked to synaptic and memory loss. Exogenous expression of $A \beta$ in neurons leads to the removal of AMPARs from synapses, which both mimics and occludes mGluR-dependent LTD (Kamenetz et al., 2003; Hsieh et al., 2006) and might originate from improper activation of CaMKII (Opazo et al., 2018). Preventing the $A \beta$-induced AMPAR loss from synapses by cross-linking surface AMPARs prevents spine loss (Opazo et al., 2018). We also recently established that AMPAR surface diffusion is disturbed in various rodent models of Huntington's disease (Zhang et al., 2018). Defects in the BDNF-TrkB signaling pathway contributes to the deregulated AMPAR trafficking in Huntington's disease models by reducing the interaction between TARPs and the PDZ-domain scaffold protein PSD95.

The stress hormone corticosterone also increases surface diffusion and expression of GluA2-containing AMPARs (Groc et al., 2008). Moreover, prior exposure to corticosterone facilitates both synaptic and extrasynaptic AMPAR endocytosis during NMDA-induced LTD (Martin et al., 2009). This suggests that stress impacts glutamatergic signaling in the hippocampus in a manner that tends to favor LTD induction over LTP (Pinar et al., 2017). Interestingly, we could pharmacologically revert the 
stress-induced (Zhang et al., 2013) and the mutant huntingtininduced (Zhang et al., 2018) LTP defects with tianeptine, an antidepressant that favors AMPAR stability. Together, these results indicate the following: (1) disease-associated defects in synaptic plasticity can arise form defective AMPAR trafficking; and (2) correcting AMPAR trafficking is a potential means to correct defective plasticity.

\section{AMPAR surface trafficking and exocytosis in LTP}

AMPAR exocytosis is mandatory to bring newly synthetized receptors to the cell surface or to return them to the surface after constitutive endocytosis. Importantly, there is strong evidence that membrane exocytosis is required for several forms of activity-dependent synaptic potentiation. The requirement of exocytosis for LTP was initially suggested using a clostridial neurotoxin to prevent membrane fusion (Lledo et al., 1998). Several studies then provided evidence for AMPAR exocytosis during LTP using either cleavage of tags on surface-expressed AMPAR (Passafaro et al., 2001) or directly visualizing exocytosis using AMPAR subunits tagged with pHluorin, a pH-dependent form of GFP (e.g., Yudowski et al., 2007; Lin et al., 2009; Kennedy et al., 2010). Exocytic events were detected mostly in the dendritic shaft (Yudowski et al., 2007; Lin et al., 2009), although a few studies have also reported their occasional direct insertion at spines (Kennedy et al., 2010; Patterson et al., 2010). Importantly, endosomes seem to provide an important reservoir of AMPARs for activity-dependent exocytosis (Park et al., 2004; Kennedy et al., 2010). In parallel, it was suggested that both lateral movement and exocytosis of AMPAR contribute to LTP (Makino and Malinow, 2009). Together, these observations seemed to indicate that the only pathway for AMPARs to enter or leave the PSD was through lateral diffusion at the neuronal surface, whereas sites of receptor endocytosis and exocytosis lie away from the PSD.

This led us to propose a three step model for AMPARs to reach synapses involving exocytosis at extrasynaptic/perisynaptic sites, lateral diffusion to synapses, and a subsequent rate-limiting diffusional trapping step (Opazo and Choquet, 2011) (Fig. 3). In a manner similar to the mechanism of LTD, the respective roles of AMPAR exocytosis, diffusion, and trapping in activitydependent increases in AMPAR number at synapses during LTP have been difficult to establish. This has been due largely to the lack of adequate tools and the fact that, for a long time, a large body of experiments involving AMPAR diffusion or exocytosis have been performed in neuronal cultures that do not express bona fide LTP.

Early on, protein $4.1 \mathrm{~N}$ was identified as a phosphorylationdependent binding partner required for activity-dependent GluA1 insertion (Lin et al., 2009). More recently, major advances in our understanding of the molecular mechanism of AMPAR exocytosis have led to the identification of complexins (Ahmad et al., 2012), specific SNARE proteins (Kennedy et al., 2010; Jurado et al., 2013), and Synaptotagmin 1 and 7 as key elements of the membrane fusion machinery during LTP (Wu et al., 2017). On the one hand, this suggests the involvement of calciumdependent regulatory machinery in AMPAR exocytosis, somewhat similar to the calcium dependence of presynaptic transmitter release. On the other hand, these studies demonstrate the absolute requirement for an intact exocytic machinery for LTP. However, several outstanding questions remain, such as whether a rise in calcium alone is sufficient to trigger AMPAR exocytosis, and exactly where and when exocytosis of endogenous AMPAR takes place during LTP.
Indeed, the relative timing of AMPAR exocytosis during LTP is still ambiguous. We and others (Makino and Malinow, 2009; Opazo et al., 2010; Opazo and Choquet, 2011; Granger et al., 2013) have proposed that the synaptic trapping of diffusive receptors already present on the neuronal surface (i.e., before exocytosis of new receptors) mediates the initial potentiation (subsecond to the first few minutes) after LTP inducing stimuli (Fig. 3). In an exciting collaboration with the group of Yann Humeau, we recently demonstrated this hypothesis directly using a surface receptor cross-linking approach (Penn et al., 2017). Diffusion trapping at synapses of AMPARs present at the surface before the LTP inducing stimuli, together with presynaptic tetanic potentiation, seems to entirely account for the initial potentiation of synaptic transmission after tetanic stimulation, before exocytosis of new AMPARs. Maintenance of potentiation beyond these first few minutes is, by contrast, strictly dependent on subsequent membrane exocytosis (Lledo et al., 1998; Jurado et al., 2013; Wu et al., 2017). While AMPAR exocytosis is likely triggered within seconds of tetanic stimuli, it probably takes minutes before newly exocytosed receptors reach synaptic sites. We have previously shown that newly exocytosed AMPARs diffuse freely at the neuronal surface (Petrini et al., 2009). Our new work further establishes that surface cross-linking of these exocytosed AMPARs in turn blocks the expression of LTP (Penn et al., 2017).

While NMDA-dependent potentiation of AMPAR responses at CA1-Schaffer collateral synapses strictly depends on surface diffusion of AMPARs, whether of preexisting or newly exocytosed AMPARs, basal synaptic transmission at these synapses is unaffected by AMPAR immobilization through cross-linking. We exploited this property to provide the first direct link between the plasticity of synaptic transmission and the expression of context-dependent fear conditioning using AMPAR immobilization (Penn et al., 2017). This indicates that manipulating AMPAR surface diffusion in vivo offers a new approach to influencing synaptic memory.

Finally, given the role of diffusion-trapping, the absolute requirement on exocytosis for LTP is somewhat intriguing. Indeed, at first glance, addition of new receptors to the cell surface should not be necessary to maintain LTP given the already large reservoir of extrasynaptic surface receptors at rest. It remains to be established whether the dependence of LTP on exocytosis relies solely, or at all, on externalization of additional AMPARs or whether exocytosis of other cargos is also required. One possibility that still needs to be investigated is whether exocytosis of other components, such as trophic factors (e.g., BDNF) (Harward et al., 2016) or of different AMPAR complexes introducing new modulatory subunits, mediates the strict dependence of LTP on exocytosis.

\section{Molecular mechanism of AMPAR stabilization at synapses}

The quest for the molecular mechanism of AMPAR stabilization at synapses has been a long journey that is far from over. Notably, the molecules and processes that mediate basal and activitydependent trapping of AMPARs at synapses have not been precisely identified. Nonetheless, major efforts have been deployed to identify potential interactor complexes that stabilize AMPARs at synapses. Interactions between AMPARs and several of these scaffold complexes and auxiliary proteins have been demonstrated to be regulated by signaling pathways triggered by neuronal activity, and have therefore been proposed to account for activity-dependent modulation of AMPAR content at synapses.

One important mechanism for stabilizing AMPARs involves binding of the AMPAR C terminus domain (CTD) with various 
interactors, such as PICK or GRIP for GluA2, and SAP97 for GluA1 (Scannevin and Huganir, 2000; Kim and Sheng, 2004). These interactions involve PDZ domains (for PSD95, DLG, and ZOO1, the main PDZ domain-containing proteins) present in most scaffold proteins at excitatory synapses. GluA1 and GluA2 have been proposed to exhibit differential trafficking properties that may rely on this differential binding (Shi et al., 2001). Studies using exogenously expressed mutant subunits in cultured hippocampal slices have suggested that the CTD of GluA1, but not of GluA2, is critical for LTP expression (Hayashi et al., 2000; Shi et al., 2001; Malinow and Malenka, 2002; Collingridge et al., 2004). Although this has been challenged (Granger et al., 2013; DíazAlonso et al., 2017), recent data using mouse strains in which the CTD of the endogenous AMPARs are switched indicate that the CTD of GluA1 and GluA2 is necessary and sufficient for NMDAR-dependent LTP and LTD, respectively (Zhou et al., 2018).

In addition, a series of seminal works identified posttranslational modifications of AMPAR-subunit CTDs as important elements in the plasticity cascade (Huganir and Nicoll, 2013), although their exact role in AMPAR stabilization at synapses is still unclear. Distinct AMPAR phosphorylation sites are regulated during bidirectional synaptic plasticity (Lee et al., 2000). Direct evidence for the role of GluA1 phosphorylation in LTP and LTD expression comes from experiments using CaMKII, PKC, and PKA phospho-null knock-in mice (Lee et al., 2003). Invariably, deficits in LTP and LTD induction were observed in these mice, coincident with significant deficits in spatial memory retention, although these mutations were not sufficient to completely occlude the expression of long-term plasticity (Lee et al., 2003). Together, these studies indicate that GluA1 phosphorylation is an important regulator of LTP and LTD, but it may not be mandatory. In particular, the roles of these phosphorylation events in modulating the binding of AMPARs to scaffold elements that are important for synaptic stabilization are unclear, and LTP is either intact or only mildly affected in mice with an altered GluA1 PDZ domain (Kim et al., 2005), in contrast to earlier indications of a requirement for PDZ domain interactions (Hayashi et al., 2000). Thus, the exact contributions of these phosphorylation events to potentiating the AMPAR response are not yet fully established. Potential roles of GluA1 phosphorylation, in addition to the above-mentioned changes in conductance, could be through regulation of their activity-dependent exocytosis (Lin et al., 2009), perisynaptic stabilization (He et al., 2009), or intracellular transport (Hangen et al., 2018).

The discovery that AMPARs are associated with a multitude of auxiliary subunits (Chen et al., 2000; Tomita et al., 2003; Nicoll et al., 2006; Schwenk et al., 2009; von Engelhardt et al., 2010; Schwenk et al., 2012; Klaassen et al., 2016; Greger et al., 2017), which regulate their function and trafficking, opened a series of new pathways to search for the mechanism of AMPAR stabilization at synapses. Of particular importance, in my view, was the identification of the TARP family of auxiliary proteins (Chen et al., 2000), several of which can bind to PSD95 through PDZ interactions. We showed that association of TARP $\gamma 2$ (i.e., stargazin) with PSD95 is mandatory for stabilization of diffusing AMPARs at the PSD (Bats et al., 2007). We, and others, established that phosphorylation of a stretch of serines in $\gamma 2$ (i.e., stargazin) TARP, possibly by CaMKII activated downstream of NMDARs, regulates its binding to PSD95 by modifying its interaction with the plasma membrane (Tomita et al., 2005; Opazo et al., 2010; Sumioka et al., 2010; Hafner et al., 2015). A similar mechanism may be at play for $\gamma 8$, the major TARP in the hippocampus. $\gamma 8$ indeed seems to be key for LTP in the hippocampus, as enhancement of AMPAR-mediated transmission, and memory, require CaMKII-dependent phosphorylation of $\gamma 8$, as shown using mice lacking CaMKII phosphorylation sites of $\gamma 8$ (Park et al., 2016). However, the role of $\gamma 8$ is debated. Despite substantial reduction of LTP in $\gamma 8 \mathrm{KO}$ mice (Rouach et al., 2005), initial studies indicated that KI mice with a deletion of the $\gamma 8 \mathrm{PDZ}$-binding domain ( $\gamma 8 \mathrm{D} 4)$ showed normal LTP (Sumioka et al., 2011). Further studies using a single-cell molecular-replacement strategy indicated that $\gamma 8$, via its PDZ-binding motif, is indispensable for both basal synaptic transmission and LTP (Sheng et al., 2018). These seemingly inconsistent results may be due to functional redundancy among the TARPs expressed in pyramidal cells. In addition, other AMPAR auxiliary subunits, such as the Shisa family, regulate AMPAR diffusion trapping (Klaassen et al., 2016) and could contribute to synaptic plasticity (von Engelhardt et al., 2010; Schmitz et al., 2017).

More generally, the increase in AMPAR number at synapses during LTP can be explained by a combined increase in both the number of AMPAR-complex binding sites in the PSD, which have been referred to as "slots" (Lisman and Raghavachari, 2006), and an increase in the affinity of the AMPAR complexes for these slots. Interestingly, using a systematic single-cell molecularreplacement strategy to replace all endogenous AMPARs with transfected subunits, it has been shown that synapses can accumulate a broad variety of receptors after LTP, shifting the focus of LTP expression from the receptor subunits to the synapse itself and specifically the PSD (Granger et al., 2013). This lends strong support to a diffusion-trapping model for potentiation of AMPAR-mediated responses in LTP (Opazo and Choquet, 2011; Penn et al., 2017).

Finally, increases in the availability of trapping slots for AMPAR complexes during potentiation could arise from unmasking of existing occupied binding sites. In this regard, CaMKII-dependent phosphorylation of the PDZ-binding protein SynGAP induces its dispersion from synapses and the addition of synaptic AMPARs during LTP (Chen et al., 1998; Kim et al., 1998; Araki et al., 2015; Walkup et al., 2016). This provides an attractive model according to which unbinding of SynGap from PSD95 would free new binding sites for AMPAR complexes. This could complement the increased affinity of TARPs for PSD95 and further explain why increases in AMPAR trapping at synapses at early times after tetanic induction is temporally decorrelated from increases in PSD95 levels, which occur at later times.

In addition to these intracellular interactions, previous and more recent evidence indicates that the extracellular $\mathrm{N}$ terminus of AMPAR subunits also interacts with various adhesion proteins or extracellular matrix components (Sia et al., 2007; Díaz-Alonso et al., 2017; Watson et al., 2017), and these interactions could also participate in AMPAR synaptic stabilization and its regulation by activity. Synaptic "slots" for AMPAR could thus also be extracellular.

Together, these data tend to favor a model in which AMPARs have a multitude of interactions that intervene at various steps of the trafficking pathway, many of them being sequentially involved in synaptic plasticity. An attractive minimal model would suggest that AMPAR-subunit CTDs are involved in controlling membrane transport between intracellular compartments and the cell surface, whereas auxiliary subunits are involved in the stabilization of surface-diffusing AMPARs at synapses. 
Nanoscale organization of AMPARs and functional implications

An important observation that emerged relatively recently is that synaptic AMPARs are not uniformly distributed in the PSD. Rather, approximately half of them are organized in stable clusters $\sim 80 \mathrm{~nm}$ diameter, termed nanodomains, whereas the remaining receptors are highly mobile between these clusters. This concept was discovered simultaneously by three laboratories, including ours, using super-resolution microscopy (Fukata et al., 2013; MacGillavry et al., 2013; Nair et al., 2013). These nanodomains seem to align with the presynaptic release machinery in a so-called nanocolumn (Tang et al., 2016). Interestingly, the number of such nanodomain modules scales linearly with spine size, and NMDAR-dependent increases in spine size are accompanied both by enhanced mobility of coaligned presynaptic and postsynaptic modules and by a coordinated increase in the total number of nanomodules (Hruska et al., 2018). The molecular mechanisms that allow this presynaptic-postsynaptic alignment has not yet been formally identified, but we have recently shown that overexpression of a truncation mutant of neuroligin 1 that cannot bind PSD95 breaks this alignment (Haas et al., 2018). Binding of neuroligin to presynaptic neurexins could thus allow aligning the release machinery to AMPAR domains. This is in line with the tripartite interaction between neuroligin, PSD95, and AMPAR complexes through TARPs (Mondin et al., 2011). Other transsynaptic adhesion complexes, such as LLRTMs, could also play important roles (Bhouri et al., 2018; Schroeder et al., 2018).

These findings have far-reaching implications for our understanding of excitatory synapse function and plasticity. First, because AMPARs have a relatively low affinity for glutamate and because individual synaptic vesicles contain a limited amount of glutamate, aligning AMPAR clusters to release sites improves synapse efficacy and reliability. Indeed, misaligning the release machinery to AMPAR nanodomain by expression of the neuroligin 1 truncation mutant markedly decreases the efficacy of synaptic transmission (Haas et al., 2018). Second, this potentially provides a new way to fine-tune synapse efficacy by regulating the location of AMPAR clusters with respect to release sites within the PSD, for example, through regulating adhesionprotein interactions. First proposed $>20$ years ago (Xie et al., 1997), this idea remains to be supported experimentally, but nonetheless, it provides an attractive nanoscale mechanism for synaptic plasticity.

Finally, alignment of AMPAR nanodomains with glutamate release sites might help explain a puzzling postsynaptic mechanism for regulation of frequency-dependent short-term plasticity that we discovered 10 years ago (Heine et al., 2008; Opazo et al., 2010; Constals et al., 2015): immobilization of AMPARs induced a decrease in paired-pulse ratio, whereas increasing AMPAR mobility did the opposite (Frischknecht et al., 2009). Although changes in paired-pulse ratio are usually taken as a hallmark of presynaptic modulation of transmitter release, we proposed at contrario that AMPAR mobility could tune short-term plasticity by allowing fast replacement of desensitized AMPARs by naive ones. This process would help speed up recovery of synaptic depression due to AMPAR desensitization during consecutive stimuli at short intervals. That AMPARs clusters are localized apposed to release sites (Tang et al., 2016) and that desensitized AMPARs move faster than naive ones (Constals et al., 2015), perhaps by detaching from TARPs, provides physical support to this hypothesis. AMPARs mobility-mediated regulation of frequency-dependent short-term plasticity could provide a new means to regulate network function.

\section{Looking forward}

Work from many laboratories over the last 20 years has established AMPAR trafficking as a fundamental process controlling synaptic efficacy during experience-dependent plasticity. Few studies have attempted to directly link the regulation of AMPAR trafficking to higher brain functions, such as memory processes (Van den Oever et al., 2008; Chiu et al., 2017) or sensory-motor function (Y. Zhang et al., 2015). Despite the wealth of knowledge we have acquired to date, it seems we have just begun to scratch the surface in understanding the molecular mechanisms of synaptic plasticity and its role in higher brain functions. Challenges that lie in front of us include both obtaining a better understanding of the nanoscale molecular organization of AMPARs and directly linking the regulation of AMPAR trafficking to synaptic plasticity, circuit function, and behavior. To address these aims, better tools are needed to image and control the dynamic organization of AMPARs in vivo, as well as to decipher the respective roles of each element of the AMPAR-containing multimolecular complex and its associated machinery for stabilization and trafficking.

Several diseases are linked directly or indirectly to perturbations of AMPAR function and organization. Mutations in various components of the AMPAR complex themselves or, more often, to proteins involved in AMPAR stabilization and trafficking, lead to a plethora of behavioral deficits and intellectual disabilities. Brain dysfunction in neurodegenerative diseases is often linked to synaptic alterations that can be attributed to AMPAR trafficking defects. In this regard, there is promise in further exploring the link between AMPAR stabilization and the structural integrity of the synapse. A better understanding of the mechanisms and roles of AMPAR trafficking in brain function can help devise new therapeutic strategies to address various aspects of brain dysfunction.

\section{References}

Ahmad M, Polepalli JS, Goswami D, Yang X, Kaeser-Woo YJ, Südhof TC, Malenka RC (2012) Postsynaptic complexin controls AMPA receptor exocytosis during LTP. Neuron 73:260-267. CrossRef Medline

Andrásfalvy BK, Smith MA, Borchardt T, Sprengel R, Magee JC (2003) Impaired regulation of synaptic strength in hippocampal neurons from GluR1-deficient mice. J Physiol 552:35-45. CrossRef Medline

Araki Y, Zeng M, Zhang M, Huganir RL (2015) Rapid dispersion of SynGAP from synaptic spines triggers AMPA receptor insertion and spine enlargement during LTP. Neuron 85:173-189. CrossRef Medline

Ashby MC, De La Rue SA, Ralph GS, Uney J, Collingridge GL, Henley JM (2004) Removal of AMPA receptors (AMPARs) from synapses is preceded by transient endocytosis of extrasynaptic AMPARs. J Neurosci 24: 5172-5176. CrossRef Medline

Ashby MC, Maier SR, Nishimune A, Henley JM (2006) Lateral diffusion drives constitutive exchange of AMPA receptors at dendritic spines and is regulated by spine morphology. J Neurosci 26:7046-7055. CrossRef Medline

Axelrod D, Ravdin P, Koppel DE, Schlessinger J, Webb WW, Elson EL, Podleski TR (1976) Lateral motion of fluorescently labeled acetylcholine receptors in membranes of developing muscle fibers. Proc Natl Acad Sci U S A 73:4594-4598. CrossRef Medline

Barria A, Muller D, Derkach V, Griffith LC, Soderling TR (1997) Regulatory phosphorylation of AMPA-type glutamate receptors by CaM-KII during long-term potentiation. Science 276:2042-2045. CrossRef Medline

Bats C, Groc L, Choquet D (2007) The interaction between stargazin and PSD95 regulates AMPA receptor surface trafficking. Neuron 53:719-734. CrossRef Medline

Baude A, Nusser Z, Molnár E, McIlhinney RA, Somogyi P (1995) Highresolution immunogold localization of AMPA type glutamate receptor subunits at synaptic and non-synaptic sites in rat hippocampus. Neuroscience 69:1031-1055. CrossRef Medline

Beattie EC, Carroll RC, Yu X, Morishita W, Yasuda H, von Zastrow M, 
Malenka RC (2000) Regulation of AMPA receptor endocytosis by a signaling mechanism shared with LTD. Nat Neurosci 3:1291-1300. CrossRef Medline

Benke TA, Lüthi A, Isaac JT, Collingridge GL (1998) Modulation of AMPA receptor unitary conductance by synaptic activity. Nature 393:793-797. CrossRef Medline

Betz H, Kuhse J, Schmieden V, Malosio ML, Langosch D, Prior P, Schmitt B, Kirsch J (1991) How to build a glycinergic postsynaptic membrane. J Cell Sci Suppl 15:23-25. Medline

Bhouri M, Morishita W, Temkin P, Goswami D, Kawabe H, Brose N, Südhof TC, Craig AM, Siddiqui TJ, Malenka R (2018) Deletion of LRRTM1 and LRRTM2 in adult mice impairs basal AMPA receptor transmission and LTP in hippocampal CA1 pyramidal neurons. Proc Natl Acad Sci U S A 115:E5382-E5389. CrossRef Medline

Blanpied TA, Scott DB, Ehlers MD (2002) Dynamics and regulation of clathrin coats at specialized endocytic zones of dendrites and spines. Neuron 36:435-449. CrossRef Medline

Bliss TV, Collingridge GL (2013) Expression of NMDA receptor-dependent LTP in the hippocampus: bridging the divide. Mol Brain 6:5. CrossRef Medline

Bliss TV, Lomo T (1973) Long-lasting potentiation of synaptic transmission in the dentate area of the anaesthetized rabbit following stimulation of the perforant path. J Physiol 232:331-356. CrossRef Medline

Borgdorff AJ, Choquet D (2002) Regulation of AMPA receptor lateral movements. Nature 417:649-653. CrossRef Medline

Bredt DS, Nicoll RA (2003) AMPA receptor trafficking at excitatory synapses. Neuron 40:361-379. CrossRef Medline

Carroll RC, Lissin DV, von Zastrow M, Nicoll RA, Malenka RC (1999) Rapid redistribution of glutamate receptors contributes to long-term depression in hippocampal cultures. Nat Neurosci 2:454-460. CrossRef Medline

Carroll RC, Beattie EC, von Zastrow M, Malenka RC (2001) Role of AMPA receptor endocytosis in synaptic plasticity. Nat Rev Neurosci 2:315-324. CrossRef Medline

Chen HJ, Rojas-Soto M, Oguni A, Kennedy MB (1998) A synaptic rasGTPase activating protein (p135 SynGAP) inhibited by CaM kinase II. Neuron 20:895-904. CrossRef Medline

Chen L, Chetkovich DM, Petralia RS, Sweeney NT, Kawasaki Y, Wenthold RJ, Bredt DS, Nicoll RA (2000) Stargazin regulates synaptic targeting of AMPA receptors by two distinct mechanisms. Nature 408:936-943. CrossRef Medline

Chiu SL, Diering GH, Ye B, Takamiya K, Chen CM, Jiang Y, Niranjan T, Schwartz CE, Wang T, Huganir RL (2017) GRASP1 regulates synaptic plasticity and learning through endosomal recycling of AMPA receptors. Neuron 93:1405-1419.e8. CrossRef Medline

Cho KO, Hunt CA, Kennedy MB (1992) The rat brain postsynaptic density fraction contains a homolog of the Drosophila discs: large tumor repressor protein. Neuron 9:929-942. CrossRef Medline

Choquet D, Triller A (2003) The role of receptor diffusion in the organization of the postsynaptic membrane. Nat Rev Neurosci 4:251-265. CrossRef Medline

Choquet D, Triller A (2013) The dynamic synapse. Neuron 80:691-703. CrossRef Medline

Chung HJ, Xia J, Scannevin RH, Zhang X, Huganir RL (2000) Phosphorylation of the AMPA receptor subunit GluR2 differentially regulates its interaction with PDZ domain-containing proteins. J Neurosci 20:72587267. CrossRef Medline

Chung HJ, Steinberg JP, Huganir RL, Linden DJ (2003) Requirement of AMPA receptor GluR2 phosphorylation for cerebellar long-term depression. Science 300:1751-1755. CrossRef Medline

Collingridge GL, Kehl SJ, McLennan H (1983) The antagonism of amino acid-induced excitations of rat hippocampal CA1 neurones in vitro. J Physiol 334:19-31. CrossRef Medline

Collingridge GL, Isaac JT, Wang YT (2004) Receptor trafficking and synaptic plasticity. Nat Rev Neurosci 5:952-962. CrossRef Medline

Collingridge GL, Peineau S, Howland JG, Wang YT (2010) Long-term depression in the CNS. Nat Rev Neurosci 11:459-473. CrossRef Medline

Constals A, Penn AC, Compans B, Toulmé E, Phillipat A, Marais S, Retailleau N, Hafner AS, Coussen F, Hosy E, Choquet D (2015) Glutamateinduced AMPA receptor desensitization increases their mobility and modulates short-term plasticity through unbinding from stargazin. Neuron 85:787-803. CrossRef Medline
Craig AM, Blackstone CD, Huganir RL, Banker G (1994) Selective clustering of glutamate and gamma-aminobutyric acid receptors opposite terminals releasing the corresponding neurotransmitters. Proc Natl Acad Sci U S A 91:12373-12377. CrossRef Medline

Dahan M, Lévi S, Luccardini C, Rostaing P, Riveau B, Triller A (2003) Diffusion dynamics of glycine receptors revealed by single-quantum dot tracking. Science 302:442-445. CrossRef Medline

Derkach V, Barria A, Soderling TR (1999) $\mathrm{Ca}^{2+} /$ calmodulin-kinase II enhances channel conductance of alpha-amino-3-hydroxy-5-methyl-4isoxazolepropionate type glutamate receptors. Proc Natl Acad Sci U S A 96:3269-3274. CrossRef Medline

Díaz-Alonso J, Sun YJ, Granger AJ, Levy JM, Blankenship SM, Nicoll RA (2017) Subunit-specific role for the amino-terminal domain of AMPA receptors in synaptic targeting. Proc Natl Acad Sci U S A 114:7136-7141. CrossRef Medline

Ehrensperger MV, Hanus C, Vannier C, Triller A, Dahan M (2007) Multiple association states between glycine receptors and gephyrin identified by SPT analysis. Biophys J 92:3706-3718. CrossRef Medline

Emptage NJ, Reid CA, Fine A, Bliss TV (2003) Optical quantal analysis reveals a presynaptic component of LTP at hippocampal Schafferassociational synapses. Neuron 38:797-804. CrossRef Medline

Foster M, Sherrington SC (1897) A textbook of physiology, Ed 7, Part 3. New York: Macmillan.

Frischknecht R, Heine M, Perrais D, Seidenbecher CI, Choquet D, Gundelfinger ED (2009) The brain extracellular matrix limits lateral diffusion of AMPA receptors and modulates short-term synaptic plasticity. Nat Neurosci 12 897-904.

Fukata Y, Dimitrov A, Boncompain G, Vielemeyer O, Perez F, Fukata M (2013) Local palmitoylation cycles define activity-regulated postsynaptic subdomains. J Cell Biol 202:145-161. CrossRef Medline

Fukaya M, Tsujita M, Yamazaki M, Kushiya E, Abe M, Akashi K, Natsume R, Kano M, Kamiya H, Watanabe M, Sakimura K (2006) Abundant distribution of TARP gamma- 8 in synaptic and extrasynaptic surface of hippocampal neurons and its major role in AMPA receptor expression on spines and dendrites. Eur J Neurosci 24:2177-2190. CrossRef Medline

Giannone G, Hosy E, Levet F, Constals A, Schulze K, Sobolevsky AI, Rosconi MP, Gouaux E, Tampé R, Choquet D, Cognet L (2010) Dynamic superresolution imaging of endogenous proteins on living cells at ultra-high density. Biophys J 99:1303-1310. CrossRef Medline

Granger AJ, Shi Y, Lu W, Cerpas M, Nicoll RA (2013) LTP requires a reserve pool of glutamate receptors independent of subunit type. Nature 493: 495-500. CrossRef Medline

Greger IH, Watson JF, Cull-Candy SG (2017) Structural and functional architecture of AMPA-type glutamate receptors and their auxiliary proteins. Neuron 94:713-730. CrossRef Medline

Groc L, Choquet D, Chaouloff F (2008) The stress hormone corticosterone conditions AMPAR surface trafficking and synaptic potentiation. Nat Neurosci 11:868-870. CrossRef Medline

Grover LM, Teyler TJ (1990) Two components of long-term potentiation induced by different patterns of afferent activation. Nature 347:477-479. CrossRef Medline

Haas KT, Compans B, Letellier M, Bartol TM, Grillo-Bosch D, Sejnowski TJ, Sainlos M, Choquet D, Thoumine O, Hosy E (2018) Pre-post synaptic alignment through neuroligin-1 tunes synaptic transmission efficiency. Elife 7:e31755. CrossRef Medline

Hafner AS, Penn AC, Grillo-Bosch D, Retailleau N, Poujol C, Philippat A, Coussen F, Sainlos M, Opazo P, Choquet D (2015) Lengthening of the stargazin cytoplasmic tail increases synaptic transmission by promoting interaction to deeper domains of PSD95. Neuron 86:475-489. CrossRef Medline

Hangen E, Cordelières FP, Petersen JD, Choquet D, Coussen F (2018) Neuronal activity and intracellular calcium levels regulate intracellular transport of newly synthesized AMPAR. Cell Rep 24:1001-1012.e3. CrossRef Medline

Harvey CD, Svoboda K (2007) Locally dynamic synaptic learning rules in pyramidal neuron dendrites. Nature 450:1195-1200. CrossRef Medline

Harward SC, Hedrick NG, Hall CE, Parra-Bueno P, Milner TA, Pan E, Laviv T, Hempstead BL, Yasuda R, McNamara JO (2016) Autocrine BDNFTrkB signalling within a single dendritic spine. Nature 538:99-103. CrossRef Medline

Hastings MH, Man HY (2018) Synaptic capture of laterally diffusing AMPA 
receptors, an idea that stuck. Trends Neurosci 41:330-332. CrossRef Medline

Hayashi Y, Shi SH, Esteban JA, Piccini A, Poncer JC, Malinow R (2000) Driving AMPA receptors into synapses by LTP and CaMKII: requirement for GluR1 and PDZ domain interaction. Science 287:2262-2267. CrossRef Medline

He K, Song L, Cummings LW, Goldman J, Huganir RL, Lee HK (2009) Stabilization of $\mathrm{Ca}^{2+}$-permeable AMPA receptors at perisynaptic sites by GluR1-S845 phosphorylation. Proc Natl Acad Sci U S A 106:2003320038. CrossRef Medline

Hebb DO (1949) In: The organization of behaviour. New York: Wiley.

Heine M, Groc L, Frischknecht R, Béique JC, Lounis B, Rumbaugh G, Huganir RL, Cognet L, Choquet D (2008) Surface mobility of postsynaptic AMPARs tunes synaptic transmission. Science 320:201-205. CrossRef Medline

Henley JM, Wilkinson KA (2016) Synaptic AMPA receptor composition in development, plasticity and disease. Nat Rev Neurosci 17:337-350. CrossRef Medline

Henley JM, Barker EA, Glebov OO (2011) Routes, destinations and delays: recent advances in AMPA receptor trafficking. Trends Neurosci 34:258268. CrossRef Medline

Hruska M, Henderson N, Le Marchand SJ, Jafri H, Dalva MB (2018) Synaptic nanomodules underlie the organization and plasticity of spine synapses. Nat Neurosci 21:671-682. CrossRef Medline

Hsieh H, Boehm J, Sato C, Iwatsubo T, Tomita T, Sisodia S, Malinow R (2006) AMPAR removal underlies Abeta-induced synaptic depression and dendritic spine loss. Neuron 52:831-843.

Huganir RL, Nicoll RA (2013) AMPARs and synaptic plasticity: the last 25 years. Neuron 80:704-717. CrossRef Medline

Isaac JT, Nicoll RA, Malenka RC (1995) Evidence for silent synapses: implications for the expression of LTP. Neuron 15:427-434. CrossRef Medline

Jaskolski F, Mayo-Martin B, Jane D, Henley JM (2009) Dynamindependent membrane drift recruits AMPA receptors to dendritic spines. J Biol Chem 284:12491-12503. CrossRef Medline

Jurado S, Goswami D, Zhang Y, Molina AJ, Südhof TC, Malenka RC (2013) LTP requires a unique postsynaptic SNARE fusion machinery. Neuron 77:542-558. CrossRef Medline

Kamenetz F, Tomita T, Hsieh H, Seabrook G, Borchelt D, Iwatsubo T, Sisodia S, Malinow R (2003) APP processing and synaptic function. Neuron 37: 925-937.

Kennedy MB, Bennett MK, Erondu NE (1983) Biochemical and immunochemical evidence that the "major postsynaptic density protein" is a subunit of a calmodulin-dependent protein kinase. Proc Natl Acad Sci U S A 80:7357-7361. CrossRef Medline

Kennedy MJ, Davison IG, Robinson CG, Ehlers MD (2010) Syntaxin-4 defines a domain for activity-dependent exocytosis in dendritic spines. Cell 141:524-535. CrossRef Medline

Kessels HW, Malinow R (2009) Synaptic AMPA receptor plasticity and behavior. Neuron 61:340-350. CrossRef Medline

Kim CH, Takamiya K, Petralia RS, Sattler R, Yu S, Zhou W, Kalb R, Wenthold R, Huganir R (2005) Persistent hippocampal CA1 LTP in mice lacking the C-terminal PDZ ligand of GluR1. Nat Neurosci 8:985-987. CrossRef Medline

Kim E, Sheng M (2004) PDZ domain proteins of synapses. Nat Rev Neurosci 5:771-781. CrossRef Medline

Kim JH, Liao D, Lau LF, Huganir RL (1998) SynGAP: a synaptic RasGAP that associates with the PSD95/SAP90 protein family. Neuron 20:683691. CrossRef Medline

Klaassen RV, Stroeder J, Coussen F, Hafner AS, Petersen JD, Renancio C, Schmitz LJ, Normand E, Lodder JC, Rotaru DC, Rao-Ruiz P, Spijker S, Mansvelder HD, Choquet D, Smit AB (2016) Shisa6 traps AMPA receptors at postsynaptic sites and prevents their desensitization during synaptic activity. Nat Commun 7:10682. CrossRef Medline

Kneussel M, Triller A, Choquet D (2014) SnapShot: receptor dynamics at plastic synapses. Cell 157:1738.e1. CrossRef Medline

Kornau HC, Schenker LT, Kennedy MB, Seeburg PH (1995) Domain interaction between NMDA receptor subunits and the postsynaptic density protein PSD95. Science 269:1737-1740. CrossRef Medline

Kristensen AS, Jenkins MA, Banke TG, Schousboe A, Makino Y, Johnson RC, Huganir R, Traynelis SF (2011) Mechanism of $\mathrm{Ca}^{2+} /$ calmodulindependent kinase II regulation of AMPA receptor gating. Nat Neurosci 14:727-735. CrossRef Medline
Kullmann DM, Nicoll RA (1992) Long-term potentiation is associated with increases in quantal content and quantal amplitude. Nature 357:240 -244. CrossRef Medline

Larkman A, Hannay T, Stratford K, Jack J (1992) Presynaptic release probability influences the locus of long-term potentiation. Nature 360:70-73. CrossRef Medline

Lee HK, Barbarosie M, Kameyama K, Bear MF, Huganir RL (2000) Regulation of distinct AMPA receptor phosphorylation sites during bidirectional synaptic plasticity. Nature 405:955-959. CrossRef Medline

Lee HK, Takamiya K, Han JS, Man H, Kim CH, Rumbaugh G, Yu S, Ding L, He C, Petralia RS, Wenthold RJ, Gallagher M, Huganir RL (2003) Phosphorylation of the AMPA receptor GluR1 subunit is required for synaptic plasticity and retention of spatial memory. Cell 112:631-643. CrossRef Medline

Lee SH, Jin C, Cai E, Ge P, Ishitsuka Y, Teng KW, de Thomaz AA, Nall D, Baday M, Jeyifous O, Demonte D, Dundas CM, Park S, Delgado JY, Green WN, Selvin PR (2017) Super-resolution imaging of synaptic and extrasynaptic AMPA receptors with different-sized fluorescent probes. Elife 6:e27744. CrossRef Medline

Liao D, Hessler NA, Malinow R (1995) Activation of postsynaptically silent synapses during pairing-induced LTP in CA1 region of hippocampal slice. Nature 375:400-404. CrossRef Medline

Lin DT, Makino Y, Sharma K, Hayashi T, Neve R, Takamiya K, Huganir RL (2009) Regulation of AMPA receptor extrasynaptic insertion by $4.1 \mathrm{~N}$, phosphorylation and palmitoylation. Nat Neurosci 12:879-887. CrossRef Medline

Lin JW, Ju W, Foster K, Lee SH, Ahmadian G, Wyszynski M, Wang YT, Sheng M (2000) Distinct molecular mechanisms and divergent endocytotic pathways of AMPA receptor internalization. Nat Neurosci 3:1282-1290. CrossRef Medline

Lisman J, Raghavachari S (2006) A unified model of the presynaptic and postsynaptic changes during LTP at CA1 synapses. Sci STKE 2006:re11. CrossRef Medline

Lissin DV, Carroll RC, Nicoll RA, Malenka RC, von Zastrow M (1999) Rapid, activation-induced redistribution of ionotropic glutamate receptors in cultured hippocampal neurons. J Neurosci 19:1263-1272. CrossRef Medline

Lledo PM, Zhang X, Südhof TC, Malenka RC, Nicoll RA (1998) Postsynaptic membrane fusion and long-term potentiation. Science 279:399-403. CrossRef Medline

Lüscher C, Xia H, Beattie EC, Carroll RC, von Zastrow M, Malenka RC, Nicoll RA (1999) Role of AMPA receptor cycling in synaptic transmission and plasticity. Neuron 24:649-658. CrossRef Medline

Lüthi A, Chittajallu R, Duprat F, Palmer MJ, Benke TA, Kidd FL, Henley JM, Isaac JT, Collingridge GL (1999) Hippocampal LTD expression involves a pool of AMPARs regulated by the NSF-GluR2 interaction. Neuron 24: 389-399. CrossRef Medline

Lynch G, Baudry M (1984) The biochemistry of memory: a new and specific hypothesis. Science 224:1057-1063. CrossRef Medline

MacGillavry HD, Song Y, Raghavachari S, Blanpied TA (2013) Nanoscale scaffolding domains within the postsynaptic density concentrate synaptic AMPA receptors. Neuron 78:615-622. CrossRef Medline

Makino H, Malinow R (2009) AMPA receptor incorporation into synapses during LTP: the role of lateral movement and exocytosis. Neuron 64:381390. CrossRef Medline

Malenka RC, Bear MF (2004) LTP and LTD: an embarrassment of riches. Neuron 44:5-21. CrossRef Medline

Malinow R, Malenka RC (2002) AMPA receptor trafficking and synaptic plasticity. Annu Rev Neurosci 25:103-126. CrossRef Medline

Malinow R, Tsien RW (1990) Presynaptic enhancement shown by wholecell recordings of long-term potentiation in hippocampal slices. Nature 346:177-180. CrossRef Medline

Mammen AL, Huganir RL, O'Brien RJ (1997a) Redistribution and stabilization of cell surface glutamate receptors during synapse formation. J Neurosci 17:7351-7358. CrossRef Medline

Mammen AL, Kameyama K, Roche KW, Huganir RL (1997b) Phosphorylation of the alpha-amino-3-hydroxy-5-methylisoxazole4-propionic acid receptor GluR1 subunit by calcium/calmodulin-dependent kinase II. J Biol Chem 272:32528-32533. CrossRef Medline

Man HY, Lin JW, Ju WH, Ahmadian G, Liu L, Becker LE, Sheng M, Wang YT (2000) Regulation of AMPA receptor-mediated synaptic transmission by clathrin-dependent receptor internalization. Neuron 25:649-662. CrossRef Medline 
Martin MG, Ahmed T, Korovaichuk A, Venero C, Menchón SA, Salas I, Munck S, Herreras O, Balschun D, Dotti CG (2014) Constitutive hippocampal cholesterol loss underlies poor cognition in old rodents. EMBO Mol Med 6:902-917. CrossRef Medline

Martin SJ, Grimwood PD, Morris RG (2000) Synaptic plasticity and memory: an evaluation of the hypothesis. Annu Rev Neurosci 23:649-711. CrossRef Medline

Martin S, Henley JM, Holman D, Zhou M, Wiegert O, van Spronsen M, Joëls M, Hoogenraad CC, Krugers HJ (2009) Corticosterone alters AMPAR mobility and facilitates bidirectional synaptic plasticity. PLoS One 4:e4714. CrossRef Medline

Masugi-Tokita M, Shigemoto R (2007) High-resolution quantitative visualization of glutamate and GABA receptors at central synapses. Curr Opin Neurobiol 17:387-393. CrossRef Medline

Matsuzaki M, Ellis-Davies GC, Nemoto T, Miyashita Y, Iino M, Kasai H (2001) Dendritic spine geometry is critical for AMPA receptor expression in hippocampal CAl pyramidal neurons. Nat Neurosci 4:10861092. CrossRef Medline

Matsuzaki M, Honkura N, Ellis-Davies GC, Kasai H (2004) Structural basis of long-term potentiation in single dendritic spines. Nature 429:761-766. CrossRef Medline

Meier J, Vannier C, Sergé A, Triller A, Choquet D (2001) Fast and reversible trapping of surface glycine receptors by gephyrin. Nat Neurosci 4:253260. CrossRef Medline

Mondin M, Labrousse V, Hosy E, Heine M, Tessier B, Levet F, Poujol C, Blanchet C, Choquet D, Thoumine O (2011) Neurexin-neuroligin adhesions capture surface-diffusing AMPA receptors through PSD95 scaffolds. J Neurosci 31:13500-13515. CrossRef Medline

Mulkey RM, Endo S, Shenolikar S, Malenka RC (1994) Involvement of a calcineurin/inhibitor-1 phosphatase cascade in hippocampal long-term depression. Nature 369:486-488. CrossRef Medline

Nair D, Hosy E, Petersen JD, Constals A, Giannone G, Choquet D, Sibarita JB (2013) Super-resolution imaging reveals that AMPA receptors inside synapses are dynamically organized in nanodomains regulated by PSD95. J Neurosci 33:13204-13224. CrossRef Medline

Newpher TM, Ehlers MD (2008) Glutamate receptor dynamics in dendritic microdomains. Neuron 58:472-497. CrossRef Medline

Nicoll RA (2017) A brief history of long-term potentiation. Neuron 93:281290. CrossRef Medline

Nicoll RA, Schmitz D (2005) Synaptic plasticity at hippocampal mossy fibre synapses. Nat Rev Neurosci 6:863-876. CrossRef Medline

Nicoll RA, Tomita S, Bredt DS (2006) Auxiliary subunits assist AMPA-type glutamate receptors. Science 311:1253-1256. CrossRef Medline

Nishimune A, Isaac JT, Molnar E, Noel J, Nash SR, Tagaya M, Collingridge GL, Nakanishi S, Henley JM (1998) NSF binding to GluR2 regulates synaptic transmission. Neuron 21:87-97. CrossRef Medline

Noel J, Ralph GS, Pickard L, Williams J, Molnar E, Uney JB, Collingridge GL, Henley JM (1999) Surface expression of AMPA receptors in hippocampal neurons is regulated by an NSF-dependent mechanism. Neuron 23: 365-376. CrossRef Medline

Opazo P, Choquet D (2011) A three-step model for the synaptic recruitment of AMPA receptors. Mol Cell Neurosci 46:1-8. CrossRef Medline

Opazo P, Labrecque S, Tigaret CM, Frouin A, Wiseman PW, De Koninck P, Choquet D (2010) CaMKII triggers the diffusional trapping of surface AMPARs through phosphorylation of stargazin. Neuron 67:239-252. CrossRef Medline

Opazo P, Viana da Silva S, Carta M, Breillat C, Coultrap SJ, Grillo-Bosch D, Sainlos M, Coussen F, Bayer KU, Mulle C, Choquet D (2018) CaMKII metaplasticity drives abeta oligomer-mediated synaptotoxicity. Cell Rep 23:3137-3145. CrossRef Medline

Park J, Chávez AE, Mineur YS, Morimoto-Tomita M, Lutzu S, Kim KS, Picciotto MR, Castillo PE, Tomita S (2016) CaMKII phosphorylation of TARPgamma- 8 is a mediator of LTP and learning and memory. Neuron 92:75-83. CrossRef Medline

Park M, Penick EC, Edwards JG, Kauer JA, Ehlers MD (2004) Recycling endosomes supply AMPA receptors for LTP. Science 305:1972-1975. CrossRef Medline

Passafaro M, Piëch V, Sheng M (2001) Subunit-specific temporal and spatial patterns of AMPA receptor exocytosis in hippocampal neurons. Nat Neurosci 4:917-926. CrossRef Medline

Patterson MA, Szatmari EM, Yasuda R (2010) AMPA receptors are exocytosed in stimulated spines and adjacent dendrites in a ras-ERK-dependent manner during long-term potentiation. Proc Natl Acad Sci U S A 107: 15951-15956. CrossRef Medline

Penn AC, Zhang CL, Georges F, Royer L, Breillat C, Hosy E, Petersen JD, Humeau Y, Choquet D (2017) Hippocampal LTP and contextual learning require surface diffusion of AMPA receptors. Nature 549:384-388. CrossRef Medline

Petrini EM, Lu J, Cognet L, Lounis B, Ehlers MD, Choquet D (2009) Endocytic trafficking and recycling maintain a pool of mobile surface AMPA receptors required for synaptic potentiation. Neuron 63:92-105. CrossRef Medline

Pinar C, Fontaine CJ, Triviño-Paredes J, Lottenberg CP, Gil-Mohapel J, Christie BR (2017) Revisiting the flip side: long-term depression of synaptic efficacy in the hippocampus. Neurosci Biobehav Rev 80:394-413. CrossRef Medline

Poo M (1982) Rapid lateral diffusion of functional A Ch receptors in embryonic muscle cell membrane. Nature 295:332-334. CrossRef Medline

Poo MM, Pignatelli M, Ryan TJ, Tonegawa S, Bonhoeffer T, Martin KC, Rudenko A, Tsai LH, Tsien RW, Fishell G, Mullins C, Gonçalves JT, Shtrahman M, Johnston ST, Gage FH, Dan Y, Long J, Buzsáki G, Stevens C (2016) What is memory? The present state of the engram. BMC Biol 14:40. CrossRef Medline

Rácz B, Blanpied TA, Ehlers MD, Weinberg RJ (2004) Lateral organization of endocytic machinery in dendritic spines. Nat Neurosci 7:917-918. CrossRef Medline

Roche KW, O’Brien RJ, Mammen AL, Bernhardt J, Huganir RL (1996) Characterization of multiple phosphorylation sites on the AMPA receptor GluR1 subunit. Neuron 16:1179-1188. CrossRef Medline

Rosenberg M, Meier J, Triller A, Vannier C (2001) Dynamics of glycine receptor insertion in the neuronal plasma membrane. J Neurosci 21: 5036-5044. CrossRef Medline

Rosendale M, Jullié D, Choquet D, Perrais D (2017) Spatial and temporal regulation of receptor endocytosis in neuronal dendrites revealed by imaging of single vesicle formation. Cell Rep 18:1840-1847. CrossRef Medline

Roth RH, Zhang Y, Huganir RL (2017) Dynamic imaging of AMPA receptor trafficking in vitro and in vivo. Curr Opin Neurobiol 45:51-58. CrossRef Medline

Rouach N, Byrd K, Petralia RS, Elias GM, Adesnik H, Tomita S, Karimzadegan S, Kealey C, Bredt DS, Nicoll RA (2005) TARP gamma-8 controls hippocampal AMPA receptor number, distribution and synaptic plasticity. Nat Neurosci 8:1525-1533. CrossRef Medline

Sanes JR, Lichtman JW (1999) Development of the vertebrate neuromuscular junction. Annu Rev Neurosci 22:389-442. CrossRef Medline

Scannevin RH, Huganir RL (2000) Postsynaptic organization and regulation of excitatory synapses. Nat Rev Neurosci 1:133-141. CrossRef Medline

Schmitz LJ, Klaassen RV, Ruiperez-Alonso M, Zamri AE, Stroeder J, RaoRuiz P, Lodder JC, van der Loo RJ, Mansvelder HD, Smit AB, Spijker S (2017) The AMPA receptor-associated protein Shisa7 regulates hippocampal synaptic function and contextual memory. Elife 6:e24192. CrossRef Medline

Schroeder A, Vanderlinden J, Vints K, Ribeiro LF, Vennekens KM, Gounko NV, Wierda KD, de Wit J (2018) A modular organization of LRR protein-mediated synaptic adhesion defines synapse identity. Neuron 99: 329-344.e7. CrossRef Medline

Schwenk J, Harmel N, Zolles G, Bildl W, Kulik A, Heimrich B, Chisaka O, Jonas P, Schulte U, Fakler B, Klöcker N (2009) Functional proteomics identify cornichon proteins as auxiliary subunits of AMPA receptors. Science 323:1313-1319. CrossRef Medline

Schwenk J, Harmel N, Brechet A, Zolles G, Berkefeld H, Müller CS, Bildl W, Baehrens D, Hüber B, Kulik A, Klöcker N, Schulte U, Fakler B (2012) High-resolution proteomics unravel architecture and molecular diversity of native AMPA receptor complexes. Neuron 74:621-633. CrossRef Medline

Selkoe DJ (2002) Alzheimer's disease is a synaptic failure. Science 298:789_ 791. CrossRef Medline

Sharma K, Fong DK, Craig AM (2006) Postsynaptic protein mobility in dendritic spines: long-term regulation by synaptic NMDA receptor activation. Mol Cell Neurosci 31:702-712. CrossRef Medline

Sheng N, Bemben MA, Díaz-Alonso J, Tao W, Shi YS, Nicoll RA (2018) LTP requires postsynaptic $\mathrm{PDZ}$-domain interactions with glutamate receptor/ 
auxiliary protein complexes. Proc Natl Acad Sci U S A 115:3948-3953. CrossRef Medline

Shi SH, Hayashi Y, Petralia RS, Zaman SH, Wenthold RJ, Svoboda K, Malinow R (1999) Rapid spine delivery and redistribution of AMPA receptors after synaptic NMDA receptor activation. Science 284:1811-1816. CrossRef Medline

Shi S, Hayashi Y, Esteban JA, Malinow R (2001) Subunit-specific rules governing AMPA receptor trafficking to synapses in hippocampal pyramidal neurons. Cell 105:331-343. CrossRef Medline

Sia GM, Béïque JC, Rumbaugh G, Cho R, Worley PF, Huganir RL (2007) Interaction of the N-terminal domain of the AMPA receptor GluR4 subunit with the neuronal pentraxin NP1 mediates GluR4 synaptic recruitment. Neuron 55:87-102. CrossRef Medline

Singer SJ, Nicolson GL (1972) The fluid mosaic model of the structure of cell membranes. Science 175:720-731. CrossRef Medline

Steinberg JP, Takamiya K, Shen Y, Xia J, Rubio ME, Yu S, Jin W, Thomas GM, Linden DJ, Huganir RL (2006) Targeted in vivo mutations of the AMPA receptor subunit GluR2 and its interacting protein PICK1 eliminate cerebellar long-term depression. Neuron 49:845-860. CrossRef Medline

Sumioka A, Yan D, Tomita S (2010) TARP phosphorylation regulates synaptic AMPA receptors through lipid bilayers. Neuron 66:755-767. CrossRef Medline

Sumioka A, Brown TE, Kato AS, Bredt DS, Kauer JA, Tomita S (2011) PDZ binding of TARPgamma-8 controls synaptic transmission but not synaptic plasticity. Nat Neurosci 14:1410-1412. CrossRef Medline

Tang AH, Chen H, Li TP, Metzbower SR, MacGillavry HD, Blanpied TA (2016) A trans-synaptic nanocolumn aligns neurotransmitter release to receptors. Nature 536:210-214. CrossRef Medline

Tao-Cheng JH, Crocker VT, Winters CA, Azzam R, Chludzinski J, Reese TS (2011) Trafficking of AMPA receptors at plasma membranes of hippocampal neurons. J Neurosci 31:4834-4843. CrossRef Medline

Tardin C, Cognet L, Bats C, Lounis B, Choquet D (2003) Direct imaging of lateral movements of AMPA receptors inside synapses. EMBO J 22:46564665. CrossRef Medline

Tomita S, Chen L, Kawasaki Y, Petralia RS, Wenthold RJ, Nicoll RA, Bredt DS (2003) Functional studies and distribution define a family of transmembrane AMPA receptor regulatory proteins. J Cell Biol 161:805-816. CrossRef Medline

Tomita S, Stein V, Stocker TJ, Nicoll RA, Bredt DS (2005) Bidirectional synaptic plasticity regulated by phosphorylation of stargazin-like TARPs. Neuron 45:269-277. CrossRef Medline

Triller A, Choquet D (2005) Surface trafficking of receptors between synaptic and extrasynaptic membranes: and yet they do move! Trends Neurosci 28:133-139. CrossRef Medline

Triller A, Cluzeaud F, Pfeiffer F, Betz H, Korn H (1985) Distribution of glycine receptors at central synapses: an immunoelectron microscopy study. J Cell Biol 101:683-688. CrossRef Medline

Van den Oever MC, Goriounova NA, Li KW, Van der Schors RC, Binnekade R, Schoffelmeer AN, Mansvelder HD, Smit AB, Spijker S, De Vries TJ (2008) Prefrontal cortex AMPA receptor plasticity is crucial for cueinduced relapse to heroin-seeking. Nat Neurosci 11:1053-1058. CrossRef Medline von Engelhardt J, Mack V, Sprengel R, Kavenstock N, Li KW, Stern-Bach Y, Smit AB, Seeburg PH, Monyer H (2010) CKAMP44: a brain-specific protein attenuating short-term synaptic plasticity in the dentate gyrus. Science 327:1518-1522. CrossRef Medline

Walkup WG, Mastro TL, Schenker LT, Vielmetter J, Hu R, Iancu A, Reghunathan M, Bannon BD, Kennedy MB (2016) A model for regulation by SynGAP-alphal of binding of synaptic proteins to PDZ-domain 'Slots' in the postsynaptic density. Elife 5:e16813. CrossRef Medline

Ward B, McGuinness L, Akerman CJ, Fine A, Bliss TV, Emptage NJ (2006) State-dependent mechanisms of LTP expression revealed by optical quantal analysis. Neuron 52:649-661. CrossRef Medline

Watson JF, Ho H, Greger IH (2017) Synaptic transmission and plasticity require AMPA receptor anchoring via its $\mathrm{N}$-terminal domain. Elife 6:e23024. CrossRef Medline

Wu D, Bacaj T, Morishita W, Goswami D, Arendt KL, Xu W, Chen L, Malenka RC, Südhof TC (2017) Postsynaptic synaptotagmins mediate AMPA receptor exocytosis during LTP. Nature 544:316-321. CrossRef Medline

Xie X, Liaw JS, Baudry M, Berger TW (1997) Novel expression mechanism for synaptic potentiation: alignment of presynaptic release site and postsynaptic receptor. Proc Natl Acad Sci U S A 94:6983-6988. CrossRef Medline

Yudowski GA, Puthenveedu MA, Leonoudakis D, Panicker S, Thorn KS, Beattie EC, von Zastrow M (2007) Real-time imaging of discrete exocytic events mediating surface delivery of AMPA receptors. J Neurosci 27:11112-11121. CrossRef Medline

Zakharenko SS, Zablow L, Siegelbaum SA (2001) Visualization of changes in presynaptic function during long-term synaptic plasticity. Nat Neurosci 4:711-717. CrossRef Medline

Zeng H, Chattarji S, Barbarosie M, Rondi-Reig L, Philpot BD, Miyakawa T, Bear MF, Tonegawa S (2001) Forebrain-specific calcineurin knockout selectively impairs bidirectional synaptic plasticity and working/episodiclike memory. Cell 107:617-629. CrossRef Medline

Zhang H, Etherington LA, Hafner AS, Belelli D, Coussen F, Delagrange P, Chaouloff F, Spedding M, Lambert JJ, Choquet D, Groc L (2013) Regulation of AMPA receptor surface trafficking and synaptic plasticity by a cognitive enhancer and antidepressant molecule. Mol Psychiatry 18:471484. CrossRef Medline

Zhang H, Zhang C, Vincent J, Zala D, Benstaali C, Sainlos M, Grillo-Bosch D, Daburon S, Coussen F, Cho Y, David JD, Saudou F, Humeau Y, Choquet D (2018) Modulation of AMPA receptor surface diffusion restores hippocampal plasticity and memory in Huntington's disease models. Nat Commun. In press.

Zhang Y, Cudmore RH, Lin DT, Linden DJ, Huganir RL (2015) Visualization of NMDA receptor-dependent AMPA receptor synaptic plasticity in vivo. Nat Neurosci 18:402-407. CrossRef Medline

Zhou Z, Liu A, Xia S, Leung C, Qi J, Meng Y, Xie W, Park P, Collingridge GL, Jia Z (2018) The C-terminal tails of endogenous GluA1 and GluA2 differentially contribute to hippocampal synaptic plasticity and learning. Nat Neurosci 21:50-62. CrossRef Medline 